glycolytic intermediate, to be formed by the action of a specific fructose 1-phosphate kinase (Slein, Cori \& Cori, 1950). It is, however, difficult to speculate on the activity of the enzyme under conditions obtaining in intact muscle owing to the lack of knowledge of steady-state concentrations of glyceraldehyde and of glycerol in muscle cytoplasm. In phosphate buffer, $\mathrm{pH} 7.4(0.05 \mathrm{M})$, with saturating concentrations of $\mathbf{D}$-glyceraldehyde and NADPH the glycerol dehydrogenase in homogenates of skeletal muscle metabolized $2800 \mathrm{~m} \mu$ moles of D-glyceraldehyde/hr./g. of muscle. Under optimum conditions, without provision for the removal of the glyceraldehyde, the rate of the reaction in the reverse direction (glycerol to $D$ glyceraldehyde) is one-tenth of this. The rate of [ $\left.{ }^{14} \mathrm{C}\right]$ glycerol conversion into ${ }^{14} \mathrm{CO}_{2}(113 \mathrm{~m} \mu \mathrm{moles} /$ $\mathrm{hr}$./g. of muscle) and incorporation into lipids $(29 \mathrm{~m} \mu \mathrm{moles} / \mathrm{hr}$./g. of muscle) in diaphragm slices (Table 1) is therefore apparently of a similar order of magnitude to the activity of glycerol dehydrogenase in skeletal-muscle homogenates.

I thank Dr P. B. Hagen for his advice and criticism during these investigations, which were supported by a grant from the Medical Research Council of Canada. The work was carried out during the tenure of a Post-Doctoral Fellowship of the Muscular Dystrophy Association of Canada.

Bloom, B. \& Foster, D. W. (1964). J. biol. Chem. 239, 967. Bush, E. T. (1963). Analyt. Chem. 35, 1024.

Chiang, C. \& Knight, S. G. (1959). Biochim. biophys. Acta, 35, 454.

Folch, J., Lees, M. \& Sloane-Stanley, G. H. (1957). J. biol. Chem. 226, 497.

Garland, P. B. \& Randle, P. J. (1964). Biochem. J. 93, 678.

Krebs, H. A. \& Henseleit, K. (1932). Hoppe-Seyl. Z. 210, 33.

Long, C. (1961). Biochemists' Handbook, p. 804. London: E. and F. N. Spon Ltd.

Moore, B. W. (1959). J. Amer. chem. Soc. 81, 5837.

Randle, P. J., Garland, P. B., Hales, C. N. \& Newsholme, E. A. (1963). Lancet, i, 785.

Rao, G. R., Ramakrishnan, T. \& Sirsi, M. (1960). J. Bact. $80,654$.

Slein, M. W., Cori, G. T. \& Cori, C. F. (1950). J. biol. Chem. 186, 763.

Wieland, O. S. \& Suyter, M. (1957). Biochem. Z. 329, 320. Whitaker, J. R. (1963). Analyt. Chem. 35, 1950.

Biochem. J. (1966) 98, $29 \mathrm{c}$

\title{
The Conversion of 7-Dehydrocholesterol into Cholesterol
}

\author{
By D. C. Wilton, M. Akhtar and K. A. Munday \\ Department of Physiology and Biochemistry, University of Southampton
}

(Received 25 November 1965)

Previous investigations from several Laboratories have established the sequence of reactions leading to synthesis of cholesterol (II) from acetate (Clayton, 1965). The mechanisms of a number of the reactions, especially those between acetate and lanosterol, have also received attention (Clayton, 1965). However, details of the reactions that result in the formation of cholesterol from lanosterol are still obscure. In the biosynthesis of cholesterol from lanosterol three methyl groups at positions 14, $4 \alpha$ and $4 \beta$ are replaced by three hydrogen atoms, the $\Delta^{24,25}$-double bond is reduced and the $\Delta \Delta^{8,9}$-double bond is replaced by one between $\mathrm{C}_{(5)}$ and $\mathrm{C}_{(6)}$.

Some recent reports suggest that the last intermediate in the biosynthesis of cholesterol (II) is 7-dehydrocholesterol (I) (Dempsey, Seaton, Schroepfer \& Trockman, 1964; Dvornik, Kraml \& Bagli, 1964); however, it has not yet been unambiguously established that 7-dehydrocholesterol is an obligatory intermediate in the biosynthesis of cholesterol.

The present communication describes the origin and stereochemistry of the two hydrogen atoms at positions 7 and 8 during the conversion of 7-dehydrocholesterol (I) into cholesterol (II) with rat-liver homogenates by the enzyme 7-dehydrocholesterol reductase. Optimum conditions for the conversion of 7-dehydrocholesterol (I) into cholesterol (II) were studied by using 7-dehydro[19-3H]cholesterol (Akhtar \& Gibbons, 1965). In all experiments 
cholesterol was isolated by preparative thin-layer chromatography and purified to constant radioactivity by the dibromide method (Fieser, 1953).

Incubation of non-radioactive 7-dehydrocholesterol $(\mathrm{I})$ in the presence of [4-3H]NADPH (Popják, Goodman, Cornforth, Cornforth \& Ryhage, 1961) gave radioactive cholesterol. Although there were individual variations, the direct transfer of hydrogen from NADPH to cholesterol was demonstrated by six independent experiments. The position of the hydrogen atom thus biosynthesized was established by the following sequence of reactions.

Cholesterol (II), on treatment with acetic anhydride, gave the acetate (III), which on treatment with $\mathrm{NaNO}_{2}$ and $\mathrm{HNO}_{3}$ yielded the nitro compound (IV). On reduction with zinc and acetic acid at $80^{\circ}$ the nitro compound gave the ketone $(\mathrm{V})$, which retained $88 \%$ of the radioactivity of the parent acetate (III). The ketone (V), when treated with methanolic $\mathrm{KOH}$, lost at least $93 \%$ of the activity of the original acetate (III). These experiments conclusively establish that in the conversion of 7-dehydrocholesterol (I) into cholesterol (II) one hydrogen atom is transferred directly from NADPH to position 7 of cholesterol.
In the second series of experiments non-radioactive 7-dehydrocholesterol (I) was incubated in the presence of tritiated water and non-radioactive NADPH. The cholesterol was processed to the ketone (V) as described above. Radioactivity measurement of the base-equilibrated ketone (V) revealed that the cholesterol biosynthesized in the presence of tritiated water contained $74 \%$ of the radioactivity at $\mathrm{C}_{(7)}$ and hence the remaining $26 \%$ at $\mathrm{C}_{(8)}$. Since we have already shown that the hydrogen at $\mathrm{C}_{(7)}$ is derived from NADPH, the presence of radioactivity at $\mathrm{C}_{(7)}$ in the tritiatedwater experiment remains to be explained. It has been suggested by Popják et al. (1961) that there is a soluble enzyme system in rat-liver homogenates that directs an equilibration of hydrogen at $\mathrm{C}_{(4)}$ of NADPH with those of water by the following sequence of reactions:

$$
\begin{array}{ll}
\mathrm{NADPH}+\mathrm{R}+\mathrm{H}^{+} & \rightleftharpoons \mathrm{NADP}^{+}+\mathrm{RH}_{2} \\
\mathrm{RH}_{2}+\mathrm{T}_{2} \mathrm{O} & \rightleftharpoons \mathrm{RT}_{2}+\mathrm{H}_{2} \mathrm{O} \\
\mathrm{RT}_{2}+\mathrm{NADP}^{+} & \rightleftharpoons \mathrm{R}+\mathrm{NADPT}+\mathrm{T}^{+}
\end{array}
$$

The radioactivity at $\mathrm{C}_{(7)}$ in cholesterol (Expt. 2 in Table 1) biosynthesized in the presence of<smiles>CC(C)CCCC(C)C1CCC2C3=CC=C4CC(O)CCC4(C)C3CCC21C</smiles>

(I)<smiles>[R2]OC1CCC2(C)C(=CCC3C(C)C(C)C32)C1</smiles>

(II) $\mathrm{R}=\mathrm{H}$

(III) $\mathrm{R}=\mathrm{CH}_{3} \cdot \mathrm{CO}$<smiles>CC(=O)OC1C=C2CC3C(C)C(C)C(C3[N+](=O)[O-])C2(C)CC1</smiles>

(IV)<smiles>CC(=O)OC1CCC23CCC(OC(C)=O)C(C)C2CC(=O)C3C1</smiles>

(V)

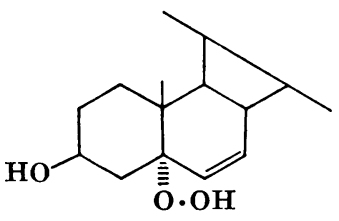

(VI)

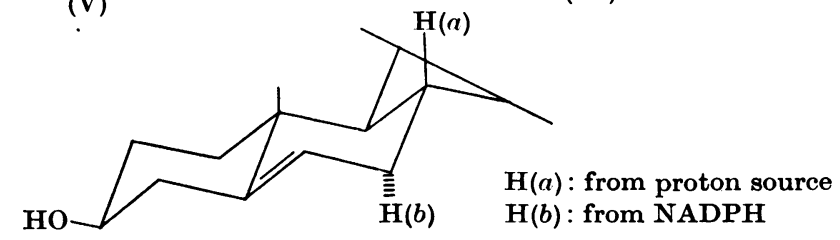

(VII) 
Table 1. Incorporation of ${ }^{3} \mathrm{H}$ into cholesterol from $\left[4 \cdot{ }^{3} \mathrm{H}\right] N A D P H$ and tritiated water on incubating 7-dehydrocholesterol with rat-liver homogenate

Samples (10 ml.) of a $500 \mathrm{~g}$ cell-free supernatant of rat-liver homogenates $(1.25 \mathrm{ml}$. of $0 \cdot 1 \mathrm{M}$-sodium phosphate buffer, $\mathrm{pH} 7 \cdot 3 / \mathrm{g}$. of liver) were incubated with $300 \mu \mathrm{g}$. of 7 -dehydrocholesterol at $37^{\circ}$ for $3 \mathrm{hr}$. under anaerobic conditions. In Expt. 1, $2 \mu$ moles of [ $\left.4-^{3} \mathrm{H}\right] \mathrm{NADPH}(6 \cdot 5 \mu \mathrm{C})$ were used, giving cholesterol of activity $2500 \mathrm{counts} /$ min. In Expt. 2, $2 \mu$ moles of NADPH and $15 \mu$ moles of glucose 6-phosphate together with 100 mc of tritiated water were used, giving cholesterol of activity 23700 counts/min. The radioactive samples were dissolved in Nuclear Enterprise 213 or 220 liquid-scintillation fluid and counted in an I.D.L. 2022 liquid-scintillation counter at $15 \%$ efficiency. Experimental error was less than $3 \%$.

Expt. 1:

Cholesterol from

$\left[4-{ }^{3} \mathrm{H}\right] \mathrm{NADPH}$

Expt. 2:

Cholesterol from

tritiated water
Activity of compounds (counts/min./m-mole)

\begin{tabular}{|c|c|c|c|c|c|c|}
\hline & ivity of com & ounds (count & $/ \mathrm{min} . / \mathrm{m}-\mathrm{mol}$ & & & \\
\hline \multirow{2}{*}{$\begin{array}{l}\text { Cholesterol } \\
\text { (II) }\end{array}$} & \multirow{2}{*}{$\begin{array}{l}\text { 6-Nitro } \\
\text { compound } \\
\text { (IV) }\end{array}$} & \multirow{2}{*}{$\begin{array}{c}\text { 6-Oxo } \\
\text { compound } \\
\text { (V) }\end{array}$} & \multirow{2}{*}{$\begin{array}{l}6-\text {-Oxo } \\
\text { compound } \\
\text { after base } \\
\text { treatment } \\
\text { (V) }\end{array}$} & \multirow{2}{*}{$\begin{array}{c}5 \alpha \text {-Hydro- } \\
\text { peroxy } \\
\text { compound } \\
(\mathrm{VI})\end{array}$} & \multicolumn{2}{|c|}{$\begin{array}{c}\text { Percentage of } \\
\text { total radioactivity }\end{array}$} \\
\hline & & & & & At $\mathrm{C}_{(7)}$ & At $C_{(8)}$ \\
\hline 5800 & - & $5120^{*}$ & 440 & - & 93 & $7 \dagger$ \\
\hline 9050 & 8800 & $7540^{*}$ & 2320 & 2520 & 74 & 26 \\
\hline
\end{tabular}

tritiated water can only have originated from NADPH formed by the equilibration reaction (3). The equilibration reaction (3) does not affect the main conclusion based on the $\left[4-{ }^{3} \mathrm{H}\right] \mathrm{NADPH}$ experiment because any equilibration of the label in this experiment would hardly affect the net radioactivity of the hydrogen atoms of water. The equilibration reaction, however, decreases the incorporation of label from $\left[4-{ }^{3} \mathrm{H}\right] \mathrm{NADPH}$ into cholesterol (II).

We now attempted to determine the stereochemistry of the hydrogen at $\mathbf{C}_{(7)}$. Cholesterol obtained from the tritiated-water experiment was converted into the $\mathbf{5} \alpha$-hydroperoxide by the method of photo-oxidation (Nickon \& Bagli, 1961). This conversion resulted in a $97 \%$ loss of label originally present at $\mathbf{C}_{(7)}$ (deduced from Table 1). It has been shown (Nickon \& Bagli, 1959) that in the conversion of cholesterol into the hydroperoxide (VI) the $7 \alpha$-hydrogen is stereospecifically lost. We therefore conclude that in the conversion of 7-dehydrocholesterol (I) into cholesterol (II) the $7 \alpha$ - and $8 \beta$-hydrogen atoms are derived from NADPH and a suitable proton source respectively. The overall addition is trans-diaxial, as shown in formula (VII).

The relative isotope effect, $3: 1$, in the formation of $\mathrm{C}_{(8)}-\mathrm{H}$ and $\mathrm{C}_{(7)}-\mathrm{H}$ bonds respectively, suggests that the crucial step in the 7-dehydrocholesterol reductase-catalysed conversion of 7-dehydrocholesterol (I) into cholesterol (II) is the formation of the $\mathrm{C}_{(8)}-\mathrm{H}$ bond, thus generating a highly stable allylic carbonium ion at $\mathrm{C}_{(7)}$ that in accordance with chemical expectations is neutralized by the delivery of a hydrogen by NADPH from the $\alpha$-side of the steroid molecule.

Avigan \& Steinberg (1961) have shown that an NADP-dependent dehydrogenase is concerned in the reduction of the side-chain double bond between $\mathrm{C}_{(24)}$ and $\mathrm{C}_{(25)}$ of steroids, and our results suggest that in this reduction the hydrogen atoms at $\mathrm{C}_{(24)}$ and $\mathrm{C}_{(25)}$ would be derived from a proton source and NADPH respectively.

D. C. W. thanks the Science Research Council for a Research Studentship.

Akhtar, M. \& Gibbons, C. J. (1965). Tetrahedron Lett. no. $9,509$.

Avigan, J. \& Steinberg, D. (1961). J. biol. Chem. 236, 2898. Clayton, R. B. (1965). Quart. Rev. chem. Soc., Lond., 19, 168.

Dempsey, M. E., Seaton, J. D., Schroepfer, G. J. \& Trockman, R. W. (1964). J. biol. Chem. $239,1381$.

Dvornik, D., Kraml, M. \& Bagli, J. F. (1964). J. Amer. chem. Soc. 86, 2739.

Fieser, L. F. (1953). J. Amer. chem. Soc. 75, 5421.

Nickon, A. \& Bagli, J. F. (1959). J. Amer. chem. Soc. 81, 6330.

Nickon, A. \& Bagli, J. F. (1961). J. Amer. chem. Soc. 83, 1498.

Popják, G., Goodman, de W. S., Cornforth, J. W., Cornforth, R. H. \& Ryhage, R. (1961). J. biol. Chem. 236, 1934. 